\title{
The Transition to Upper Secondary Level After Basic Education for Adolescents with Autism Spectrum Disorder in Finland
}

\section{Pesonen, Henri}

Springer

2019-10

Pesonen , H , Pirttimaa , R , Rämä , I \& Kontu , E 2019 , The Transition to Upper Secondary Level After Basic Education for Adolescents with Autism Spectrum Disorder in Finland . in X Hu \& E Kärnä (eds), Educating Students with Autism Spectrum Disorder in China and Finland . New Frontiers of Educational Research , Springer , Singapore , pp. 207-223 . https://doi.org/10.1007/978-9

http://hdl.handle.net/10138/310182

https://doi.org/10.1007/978-981-13-8203-1_14

unspecified

acceptedVersion

Downloaded from Helda, University of Helsinki institutional repository.

This is an electronic reprint of the original article.

This reprint may differ from the original in pagination and typographic detail.

Please cite the original version. 


\title{
Chapter 14 \\ The Transition to Upper Secondary Level After Basic Education for Adolescents with Autism Spectrum Disorder in Finland
}

\author{
Henri Pesonen, Raija Pirttimaa, Irene Rämä, and Elina Kontu
}

\begin{abstract}
This chapter provides an exploration of the preparation of pupils with autism spectrum disorder (ASD) for transition to upper secondary level after Finnish basic education. It also examines the importance of supports required during the transition phase. Two examples of pupils with ASD (Kalle and Maija) are utilized to illustrate how to plan and support pupils with ASD during their initial post-school transition. Transitions are defined, after which education opportunities after basic education for pupils with ASD in Finland are examined. This is followed by a brief illustration of the Finnish comprehensive school system to provide context with a focus on support arrangements and the preparation of support for transition. Then, the individual transition-planning documents are examined, after which the two cases of Kalle and Maija are introduced. This is followed by an illustration of the use of the documents in practice for the two pupils. The summary includes a discussion of implications for future directions.
\end{abstract}

\subsection{Transition}

Transitions in educational research, particularly in special education, are considered changes that individuals experience during the transition from compulsory schooling to vocational education or to upper-secondary education (or high school in the USA)

\footnotetext{
H. Pesonen $(\bowtie) \cdot$ E. Kontu

Faculty of Educational Sciences, University of Helsinki, Helsinki, Finland e-mail: henri.pesonen@helsinki.fi; elina.kontu@helsinki.fi

R. Pirttimaa

Faculty of Education and Psychology, University of Jyväskylä, Jyväskylä, Finland e-mail: raija.pirttimaa@jyu.fi

I. Rämä

Faculty of Educational Sciences, Centre for Educational Assessment, University of Helsinki, Helsinki, Finland

e-mail: irene.rama@helsinki.fi
} 
(Myklebust 2002; Newman and Blackburn 2002). Transitions are more or less permanent changes that might be challenging for individuals with special needs without appropriate support (Myklebust 2002), as the transition to post-school education can create disruptions in established routines (Ferguson et al. 1988). These disruptions might be challenging for all pupils entering a new educational context, particularly for individuals with special educational needs. Familiar routines are interrupted in transitions and, thus, can be difficult to confront (Transitions n.d.). For example, without appropriate transition support, individuals with ASD might not be able to reach their full potential in upper secondary level. A review study of transition practices for persons with ASD suggests that appropriate support and efficient transition planning can increase the number of successful transitions (Hendricks and Wehman 2009).

Research further indicates that individuals with ASD will continue to exhibit their unique characteristics across their lifespan (Van Bergeijk et al. 2008), which places a significant emphasis on studies related to the importance of effective transition strategies for individuals with ASD (e.g., Camarena and Sarigiani 2009; Rydzewska 2012; Van Bergeijk et al. 2008; Zager and Alpern 2010). In Finland, pupils with special educational needs — including those with ASD_might continue to experience challenges after basic education, and some become socially excluded from their communities and from meaningful participation in society (e.g., Brunila et al. 2011; Jahnukainen, 1999; Jahnukainen and Järvinen 2006). Therefore, efficient transition planning and documentation of support arrangements is extremely important. First, pupils with ASD need to be aware of different educational opportunities after basic education. From early on, particularly during their final years of basic education (between seventh and ninth grades, usually aged 13-16), pupils with ASD are prepared for future directions. For example, the special education teachers and school guidance counselors meet with each pupil to discuss their hopes and expectations for future education tracks. An examination of the different education tracks possible in the Finnish education system follows (see also Fig. 14.1.).

\subsection{Education Opportunities for Pupils with Autism Spectrum Disorders after Basic Education in Finland}

After basic education in Finnish comprehensive school (7-16-year-olds), pupils with ASD can continue their studies on the secondary education level either on a vocational track or on an academic track in upper-secondary school. Furthermore, pupils with ASD can attend additional education after earning the Finnish basic education diploma.

Vocational and academic tracks usually take 3 years to complete and provide eligibility to continue to higher education or to the labor market (Finnish National Board of Education 2016a). Although entering further education after comprehensive school is not compulsory, Finnish policy encourages everyone with and without special educational needs to continue studying. Most pupils (92\%) leaving school 


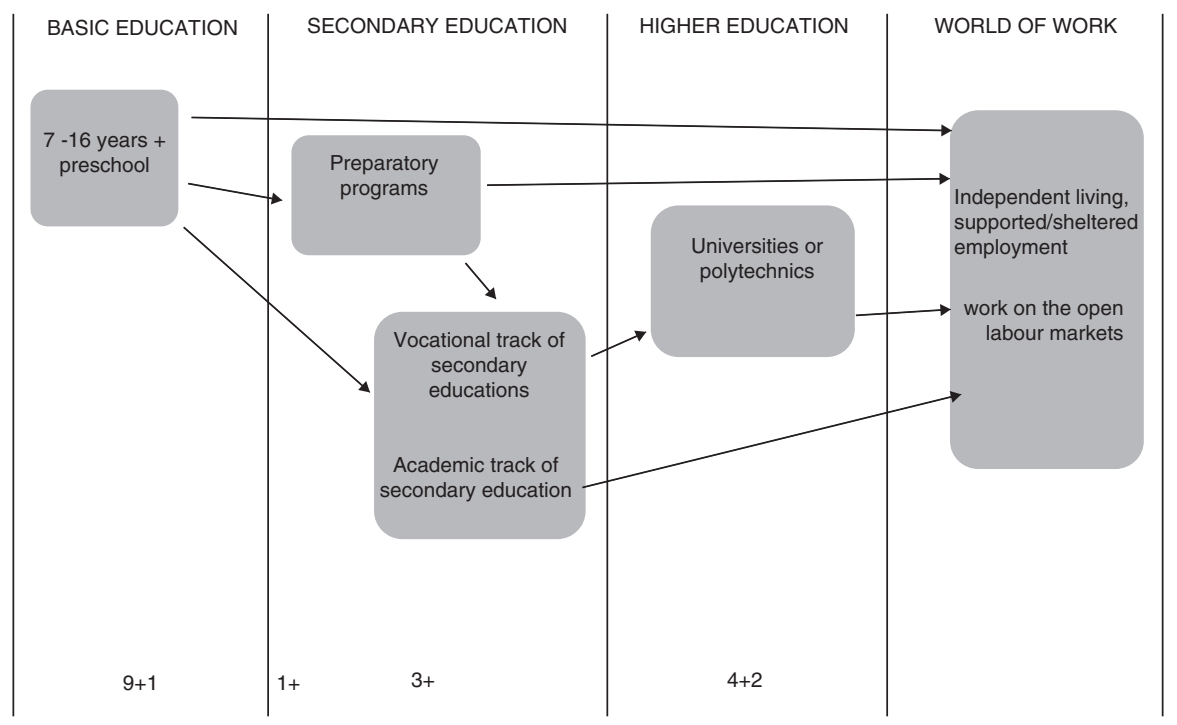

Fig. 14.1 Education tracks after basic education for pupils with ASD in Finland (Adapted from Vocational Education and Training in Finland n.d.)

begin their further education soon after completing compulsory school. From this total percentage of all pupils, $78-81 \%$ with special needs find their post-school education placement after compulsory school (Kirjavainen et al. 2013). The pupils with an individualized curriculum generally do not transition or continue to uppersecondary education as often as their peers without special needs, and pupils with individualized education plans enter vocational schooling more often than the academic track in upper-secondary level (Kirjavainen et al. 2013).

\subsubsection{Vocational Education Track in Secondary Education}

Pupils with ASD can enter vocational education institutions after compulsory schooling. They can apply using the national joint application system or through related flexible application procedures. Sometimes pupils with ASD might also apply directly to the vocational institution (European Agency for Special Needs and Inclusive Education [EU Agency] 2015). After the entrance, pupils with ASD can complete a vocational qualification at the upper-secondary vocational institution, apprenticeship training, or earn competence-based qualifications. Vocational qualifications are possible to attain at vocational institutions, at adult education institutions, and through apprenticeship training. Vocational education and training might be provided by local authorities, joint municipal authorities, registered associations or foundations, or state-led schools (EU Agency 2015; Virolainen and Stenström 2014). Generally, most of these education providers are public authorities. 
All pupils in vocational education and training have the right to receive sufficient personal and other educational guidance according to their individual needs. Vocational institutions are required to pay particular attention to the education and support of pupils with learning difficulties (Finnish National Board of Education 2016b). Vocational special needs education and training is provided in inclusive vocational institutions. There are also separate vocational special schools, which offer intensive special educational supports. These mostly aim to serve pupils with severe disabilities, illnesses and learning difficulties. Pre-vocational programs are also organized for pupils with special educational needs. For example, pre-education consists of remedial teaching, rehabilitation, and instruction for vocational track studies. There is also coaching available for those pupils who do not wish to enter vocational education. This couching prepares them for life and independent living (Koulutuksen perusteet 2015a, b; Laki ammatillisesta koulutuksesta (Vocational education legislation) 531/2017).

Enrolment in the vocational education training programs has increased during the last decades (Virolainen and Stenström 2014). In 2009, the majority of young people chose the vocational track as their first choice (Cedefop 2012). Honkanen and Nuutila (2013) have noticed that the vocational education track is also popular among pupils with special educational needs in Finland. Over $30 \%$ of vocational education track pupils have been identified as in need of individualized supports (Hirvonen et al. 2009). In 2012, approximately $86 \%$ of pupils with special needs attended education in inclusive vocational institutions, and $13 \%$ were enrolled in special vocational institutions (Official Statistics Finland 2012). Among young people studying in inclusive vocational institutions, about $15 \%$ were pupils with special needs, of whom about $79 \%$ were included with pupils without such needs. Perhaps inclusive education in Finland is not only the focus of educational policy but also the most prevalent educational practice. According to the Official Statistics of Finland from 2007, pupils who received special supports in the vocational education track and had a diagnosis of autism or Asperger's syndrome was $1.2 \%$, and $83.1 \%$ of the pupils were male.

\subsubsection{Upper-Secondary Education}

Although special needs education is not clearly stated in upper-secondary education regulations (629/1998, 810/1998), the existing Upper-Secondary Schools Act (629/1998) aims to provide support for pupils with special needs (e.g., ASD), as well as other assistive services required for the successful completion of their studies (www.european-agency.org). For example, this can include special aiding equipment for those with visual impairments. Furthermore, for the final matriculation examinations (final exams in the Finnish upper-secondary school = academic track), pupils with special needs might request easing of the terms for completing the examination or exemption from completing a specific part. For example, pupils with hearing impairments might request exemption from listening comprehension. 


\subsubsection{Additional Education}

Pupils (including those with ASD) who have completed basic education can attend additional education for one extra school year. This is stated in the Basic Education Act (1998). The additional education does not have a separate curriculum, and it is for pupils who have completed their basic education in the same or previous school year. The curriculum in additional education might consist of core subjects that were taught in basic education, as well as preparation for vocational education (EU Agency 2015). Generally, additional education provides a supplementary year to prepare for the vocational or academic track. This extra year might be highly individualized, which can serve pupils with ASD who want to enter the education track they wish to complete in the future.

\subsection{Groundwork for Preparing Pupils with ASD for Transitions in Finland}

In Finland, the groundwork for supporting and preparing individuals with ASD for transitions and education after comprehensive schooling is the Finnish school system's three-tiered support model (see the Basic Education Act 642/2010 and the Basic Education Act 628/1998). Finland's 9-year, tuition-free comprehensive school system follows the Basic Education Act of Finland (628/1998), which promotes actions intended to help pupils with ASD to gain knowledge and skills needed in further education. The Finnish education legislation consists of three tiers of support: The first tier is provided in the regular classroom; the second tier consists of targeted educational interventions and intensified support; and the third tier is special education, which is provided partly or fully in special educational settings or schools. Pupils with ASD receive support arrangements based on the nature and the extent of their needs, as well as their strengths (Finnish Basic Education Act 642/2010). Early recognition is vital, so is providing individualized support as long as is deemed necessary. The aim of the legislation is to provide support for struggling pupils in classrooms with their peers and intensified support to reduce placements in full-time special educational settings (Kirjavainen et al. 2016). Furthermore, the support services should be educationally determined (Ahtiainen et al. 2012; Itkonen and Jahnukainen 2010), given that official medical diagnoses-including ASD diagnoses - are not required for pupils to receive special education services (Thuneberg et al. 2013). The support should be based on a pupil's educational strengths and needs. The following section briefly describes post-school transition planning in Finland. 


\subsection{Post-School Transition Period and Transition Planning in Finland}

The Basic Education Act (2010) of Finland does not mandate separate transition planning as part of pupil documentation, especially after comprehensive school (ages 16 and above). Although such transition planning legislation does not exist, there are various procedures that different schools and municipalities follow to help pupils with ASD achieve their full potential. Although transition planning is totally voluntary, yet efficient planning is vital, as pupils with ASD might continue to experience challenges after comprehensive school, and some become socially excluded from their communities and from meaningful participation in society (e.g., Brunila et al. 2011; Jahnukainen 1999; Jahnukainen and Järvinen 2006). Therefore, efficient transition planning and documentation of support arrangements for individuals with ASD is of the utmost importance. The following section provides examples of individual transition plans and illustrates how they can be utilized in practice.

\subsection{Transition Planning Documentation}

The following document is used as an example of a document that might be used in a school in a Finnish municipality toward the end of ninth grade (usually at the ages of 15-16) in basic education. Although this documentation has all the necessary elements, these might vary from one municipality to another (Pesonen 2016). This can be explained by the autonomy schools and municipalities have in implementing special education legislation (Pesonen et al. 2015). Furthermore, the documentation might be a paper version that is completed by hand or entirely online.

\subsubsection{Transition Plan: ABC School}

This plan is drawn up together with the pupil and her or his parents or guardians, when she or he moves from primary education to secondary education or into a new environment. Plans are to be submitted to the next school to the group supervisor or the pupil counselor during the first transition meeting. The transition-planning document used as an example in this chapter provides the information that is usually collected during the transition-planning meeting. The transition-planning team typically consists of the pupil, significant others to the pupil, teachers, school guidance counselor, and other professionals (e.g., school psychologist, physical therapist). The meeting usually takes place during the final year of basic education (ninth grade). The goals that are discussed during the meeting are to be based on the pupil's preferences, hopes, and dreams for the future. The amount and types of transition 
goals depend on the pupil's individual needs. A look at the transition-planning document section by section follows. The plan includes the following details:

1. Basic Information: This includes the name of the pupil and contact information as well as information on parents or guardians and the name of the present school. In this part of the documentation, the pupil's basic information is collected. In addition, the names of the pupil's parents or guardians are marked in this section, which is followed by information on the present school and the contact person at that school who can provide additional information if needed. Usually the contact person is the special education teacher or the school guidance counselor. For example, if the pupil has studied mainly in an inclusive general educational setting, the contact person most likely would be the guidance counselor.

2. Strengths and Interests of the Pupil at School, Home, and Leisure Time: These include questions such as which activities does the pupil find meaningful, what makes her or him enthusiastic, what are her or his hobbies?

An effective transition-planning document includes in-depth information about the pupil's strengths and interests both in and outside the school context. Therefore, it is important to discuss with the pupil and perhaps with their parents or guardians as well to ensure that the pupil's strengths and abilities are accommodated when planning their future education. In addition, it is essential to discuss and describe the pupil's learning profile in order to inform the next education institution. For example, the section called learner profile can consist of information about native language, math, foreign languages, mastering the content of school subjects, arts, practical subjects, enthusiasm, motivation, ability to concentrate, ability to learn new things, regularity, responsibility for schoolwork, following school rules, and frequently used study methods.

3. Learning Profile and Supports Needed: These include native language, math, foreign languages, mastering the content of school subjects, arts, practical subjects, enthusiasm, motivation, ability to concentrate, ability to learn new things, regularity, responsibility for schoolwork, following school rules, and frequently used study methods.

After the strengths and the learner profile parts of the document, the required supports are planned and listed. The planned supports should take into account information about strengths and interests and use this information to support the areas where individual supports might be needed. For example, a person might excel in math and, therefore, will be offered advanced math in upper-secondary school. Yet, the pupil might have problems with social interaction; for this reason, the future education placement might consider this as grouping pupils in such a way during group work that supports the pupil's unique characteristics.

4. Social Skills and Supports Needed: These include interactional skills, friends, behavior, group work skills, human relations, adjustment to social situations, ability to ask for help, and responding to guidance and instruction.

This part of the transition-planning document describes the pupil's social skills. This is mainly based on information provided by teachers and other 
professionals in the multidisciplinary team. The description includes information about friends, relationships with peers in class, behaviors in school, group work skills, relationships with adults in school (e.g., teachers and classroom/ personal assistants), adjustment to social situations, the ability to ask for help, and responding to guidance and instruction, for instance. After the aforementioned description, the required supports are explained. This might include information on how to support the pupil's relationships with adults and other pupils.

5. Well-Being (physical and mental health issues):

The well-being section of the transition-planning document includes information about the pupil's physical and mental health conditions. This might include appendices from a physician, school psychologist, or professional other than an educator. These are utilized to inform the future multidisciplinary teams of professionals.

6. Adaptive Skills:

These include everyday routines, life habits, daily rhythm, leisure time activities, economic independence, transportation, timetable awareness, responsibility for personal issues, and own health. The existing adaptive skills are listed in this part of the transition-planning document. Also, the required supports during and after transition to the new education institution are described here. For example, this part might include how to support everyday life habits, leisure time activities, economic independence, transportation, personal issues, and own health.

7. Other Issues:

Other issues might include information about the supports from the family or others, emotions, executive functions, imitativeness, coordination skills, attention span, and ability to concentrate. This is followed by the views of the parents or guardians who are present at the transition-planning meeting.

8. Information Transmission Permission:

This part of the document is to give permission to transfer the information discussed during the transition-planning meeting to the new school's guidance counselor or group leader as well as permits the present school to send the individual education plan (IEP) to the next school as an attachment to the transition plan. In addition, there can be permission to give the parents or guardians information on how studies are progressing in the chosen education track after Finnish basic education.

\subsection{Cases}

The following are two pupil cases called Kalle and Maija. They are both finishing basic education in Finland and will soon be going through the transition planning that consists of meetings and careful documentation of their future directions. 


\subsubsection{Kalle's Case}

Kalle is a 16-year-old pupil who loves to cook and spend time with his family and friends. He was diagnosed with low-functioning autism at a very young age. He does not communicate verbally and has received most of his education in special schools or in special classes within mainstream basic education. Although Kalle's early education was tainted by his fear of social situations, he received individualized support in preschool at the age of 6, which helped him in the beginning of basic education. As a first grader, Kalle was placed in a self-contained special education class within a mainstream school. He had assistants and teachers working with him. When Kalle went to second grade, he was placed in a special school. His fear of social situations increased again. Therefore, he spent the last 2 months of third grade and the entire fourth grade in a children's hospital school. During the intensive treatment period, he gained more strength in social competence, and he returned to the special school for the fifth and sixth grades. When Kalle went to seventh grade, he continued in the special school, where a majority of pupils were severely disabled and diagnosed with ASD. Throughout his basic education, a multidisciplinary team of professionals (e.g., teachers, psychologists, medical doctors, and rehabilitation personnel) and Kalle's parents made sure that the schools considered his individual support needs efficiently. At the end of ninth grade, at the age of 16, Kalle completed basic education, and after the summer, he moved away from home. He started studying at a vocational education institution with supported residential arrangements.

\subsubsection{Response to Kalle's Case: Making a Transition Plan}

Kalle's transition team consisting of Kalle, a special education teacher, the current personal assistant, and Kalle's parents, as well as the person responsible for the support arrangements in the residential unit, decided, with respect for Kalle's own desires, that he participate in a vocational institution majoring in catering to become a cook. During the meeting, Kalle clearly expressed his career preferences about achieving a degree in catering. This would mean participation in different classes and in practical training opportunities, including a restaurant near Kalle's home. A teacher or aide is to be with Kalle at all times, or at least when necessary, especially during the first year of study and during practical field experiences. Below is the transition plan (see Fig. 14.2) that was made during the transition-planning meeting. All the parties present at the meeting helped to create this plan. All the listed details helped in planning and organizing individualized support for Kalle. Most important, Kalle played the key role during the transition-planning meeting, and his voice for future targets was respected. 


\begin{tabular}{|c|}
\hline $\begin{array}{l}\text { Name of the pupil and contact information } \\
\text { Kalle Mäkinen } \\
\text { Study Street } 1 \\
12345 \text { Helsinki, Finland } \\
\text { kalle@transitionplan.fi }\end{array}$ \\
\hline $\begin{array}{l}\text { Name/s of parents/guardians and contact information } \\
\text { Mr. \& Mrs. Mäkinen } \\
\text { Study Street } 1 \\
12345 \text { Helsinki, Finland }\end{array}$ \\
\hline $\begin{array}{l}\text { Present school and contact person, and contact information } \\
123 \text { School } \\
\text { Present School Street } \\
12345 \text { Helsinki, Finland }\end{array}$ \\
\hline $\begin{array}{l}\text { STRENGTHS, INTERESTS OF THE PUPIL AT SCHOOL, HOME, AND } \\
\text { LEISURE TIME (in what is the pupil successful, which activities does the pupil find } \\
\text { meaningful, what makes her/him enthusiastic, what are her/his hobbies) } \\
\text { Kalle enjoys spending time with family and friends; he is a social young man. Kalle } \\
\text { attends painting classes during his leisure time. He enjoys painting pictures of nature as } \\
\text { well as taking photos. } \\
\text { Kalle enjoys cooking and is keen on trying different things when cooking. He also knows } \\
\text { how to bake. Kalle and his family also eat out so he is well aware of the restaurants in the } \\
\text { city of Helsinki. }\end{array}$ \\
\hline $\begin{array}{l}\text { LEARNING PROFILE (For example, native language, math, foreign languages, } \\
\text { mastering the content of school subjects, arts, practical subjects, enthusiasm, motivation, } \\
\text { ability to concentrate, ability to learn new things, regularity, responsibility for school } \\
\text { work, following school rules, frequently used study methods) } \\
\text { Kalle's native language is Finnish. He has also studied English and some Swedish during } \\
\text { his basic education. He has been an active pupil during physical education, but subjects } \\
\text { that demand lots of reading and independent work require individualized support } \\
\text { arrangements in the classroom, for example, differentiation and an adult providing } \\
\text { prompts frequently. } \\
\text { Kalle is motivated and he can concentrate on task when it is differentiated to meet his } \\
\text { support needs. He follows school rules well. Kalle needs the help of an aide quite } \\
\text { frequently as he needs prompts to stay on the differentiated assignments during class. He } \\
\text { is a very practical learner and enjoys practical tasks, whereas assignments that are more } \\
\text { academic can cause him to struggle if they are not meeting his support needs. } \\
\text { (For example, native language, math, foreign languages, mastering the content of school } \\
\text { subjects, arts, practical subjects, enthusiasm, motivation, ability to concentrate, ability to } \\
\text { learn new things, regularity, responsibility for school work, following school rules, } \\
\text { frequently used study methods) }\end{array}$ \\
\hline $\begin{array}{l}\text { Supports needed } \\
\text { Differentiation in academic assignments. Also, modifications of exams (i.e., done in small } \\
\text { chunks). } \\
\text { Personal assistant and/or teacher available to give prompts and support during class. } \\
\text { Independent work can be challenging at times without support. }\end{array}$ \\
\hline
\end{tabular}

Fig. 14.2 $A B C$ transition plan 
SOCIAL SKILLS (for example, interactional skills, friends, behavior, group work skills, human relations, adjustment to social situations, ability to ask for help, responding to guidance and instruction)

Kalle is often shy and can be withdrawn with his friends. He can demonstrate challenging behavior if his relationships with new people are not supported. He also responds well to other people after intensive support arrangements in the beginning.

\section{Supports needed}

Ongoing social instructional support in peer relationships, especially in the beginning of new schooling.

WELLBEING (physical and mental health issues)

Kalle enjoys Nordic walking and he attends yoga at the local gym.

Notice/observe

Kalle needs help with signing up for a yoga class.

ADAPTIVE SKILLS (everyday routines, life habits, daily rhythm, leisure time activities, economic independence, transportation, timetable awareness, responsibility for personal issues and own health)

Kalle is independent and is able to take care of himself. However, he needs supervision, for example, to ensure that he follows up his daily routines.

\section{Supports needed}

Specifically, making sure that Kalle receives help with registering and signing up for leisure time activities. It is important that Kalle attends leisure activities so he has opportunities to make new friends.

OTHER ISSUES (supports from the family or other important others, emotions, executive functions, imitativeness, coordination skills, attention span and ability to concentrate)

Smart phone for Skype or Facetime calls so that Kalle can frequently communicate with family.

\section{PARENTS/GUARDIANS VIEWS}

Kalle's parents have been discussing with him the changes to come after comprehensive school. His parents are worried about safety issues if Kalle moves from home to a group home or pupil facilities. Will he get enough support and teaching about how to take care of himself, as well as how to use public transportation to come home on weekends.

\section{INFORMATION TRANSMISSION PERMISSION}

Information about the needed supports may be circled in the part below:

to school counselor/ group leader

IEP is sent to the next school as an attachment to this transition plan

Parents/guardians want to know how studies are progressing

Persons involved in this planning

Date and place

Signatures of

Pupil

Parent/guardian

Contact person in the current school

Fig. 14.2 (continued) 


\subsubsection{Maija's Case}

Maija is a 16-year-old pupil who is extremely talented in music and in math. Although she has been academically successful throughout her basic education and is planning to pursue an academic track in upper-secondary education, her abilities are challenged by some of her characteristics of Asperger's syndrome. In particular, her occasional barriers to social interaction with other people can make her feel frustrated and lonely. Maija's first experiences of school go back to a special education daycare group when she was 5 years old. After a year in special education day care, Maija began in a special education preschool group. As a first grader, Maija started in a local special school. Especially, during first grade, her teacher discovered her abilities and started to support them. The special education teacher worked in collaboration with classroom assistants, and they utilized structured and individualized pedagogical methods as much as they could. When Maija completed elementary school at the age of 13 , she transferred to a fully inclusive secondary school in Finnish basic education. She received support from the special education teacher and a classroom assistant when needed. At the age of 16, when Maija was finishing basic education, she was encouraged to continue education in upper-secondary school. A school guidance counselor set up a meeting to discover Maija's wishes for further education.

\subsubsection{Response to Maija's Case: Making a Transition Plan}

Maija's transition team, which consisted of Maija, the current special education teacher, Maija's parents, an upper-secondary school guidance counselor, as well as the future special education teacher, decided, with respect for Maija's own hopes and dreams, that she should start at an upper-secondary school close to home after summer break. From the beginning of the transition meeting, Maija made clear that she would like to pursue an academic track toward applying to a university after upper-secondary school. She dreams about studying math, chemistry, and physics and possibly becoming a subject teacher in natural sciences in the future. Below is the transition plan that was created during the transition-planning meeting (see Fig. 14.3). The persons that attended the meeting helped to create the following transition plan. The details listed in the transition-planning document help organize studies and necessary supports for Maija, who is the key person during the transition plan meeting.

The transition-planning documents for Maija and Kalle illustrate the possibilities for how they can be utilized. These examples demonstrate how systematic and precise transition planning and follow-up can facilitate pupils with ASD to successfully transition to post-school life and adulthood. A chapter summary and implications for future directions follow. 


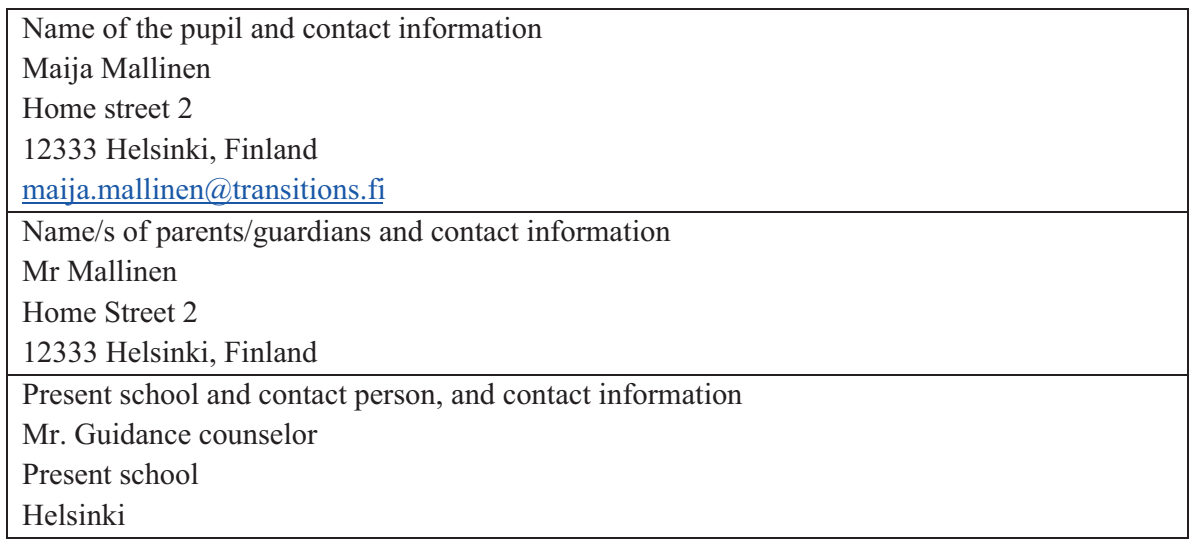

STRENGTHS, INTERESTS OF THE PUPIL AT SCHOOL, HOME AND LEISURE

TIME (in what is the pupil successful, which activities does the pupil find meaningful, what makes her/him enthusiastic, what are her/his hobbies)

It is clear for all that Maija has thought about her future carefully. She has discussed her hopes to follow an academic track at home and at school. She is highly interested in all issues linked with science. She is a devoted reader and uses the Internet a lot. She reads science magazines and is eager to share the hobby in birdwatching with her father.

LEARNING PROFILE (For example, native language, math, foreign languages, mastering the content of school subjects, arts, practical subjects, enthusiasm, motivation, ability to concentrate, ability to learn new things, regularity, responsibility for school work, following school rules, frequently used study methods)

Maija has high grades in math, languages, and science. She has experienced difficulties in participating in sports, but she says that she understands the meaning of non-academic subjects in school. She prefers to work with her closest friend or alone.

Supports needed

Maija should be provided with a study tutor or access to a study guidance counsellor's support when she needs it.

SOCIAL SKILLS (for example interactional skills, friends, behavior, group work skills, human relations, adjustment in social situations, ability to ask for help, responding to guidance and instruction)

Maija knows what the demands in school are in regard to academic subjects and social relations. She can concentrate easily on the school's tasks and gets good grades. Parents and teachers express their worries only for social aspects. Is Maija too devoted to academic tasks and has no time to build connections with other young people? Maija is also aware that sometimes she is very demanding on herself when studying.

Fig. 14.3 123 school transition plan 


\begin{abstract}
Supports needed
Encouraging Maija to take up hobbies, for example, that would help her to get more friends and develop social relationships with other people. Hobbies such as gym or Zumba classes would not directly involve social interaction but would give the opportunity to interact with others.

WELLBEING (physical and mental health issues)

Physically Maija is ok. Regular contacts with the pediatrician will continue for another twothree years. She has sometimes deep concerns about her future and feelings of loneliness.

Notice/observe

ADAPTIVE SKILLS (everyday routines, life habits, daily rhythm, leisure time activities, economic independence, transportation, timetable awareness, responsibility for personal issues and own health)

Encouraging Maija to take up a hobby or join leisure time activities.
\end{abstract}

\title{
Supports needed
}

OTHER ISSUES (supports from the family or significant others, emotions, executive functions, imitativeness, coordination skills, attention span and ability to concentrate)

Maija's parents are very supportive and work in collaboration with the school and other multidisciplinary teams of professionals.

\section{PARENTS/GUARDIANS VIEWS}

Parents accept and support the plan to continue studies in the local secondary school. Not many changes in everyday life will be required. Some of the teachers are also the same as at the comprehensive school.

\section{INFORMATION TRANSMISSION PERMISSION}

Information about the needed supports may be circled in the part below:

to school counselor/ group leader

IEP is sent to the next school as an attachment to this transition plan

Parents/guardians want to know how studies are progressing

Person involved in this planning

Date and place

Signatures of

Pupil,

Parent/guardian

Contact person in the current school

Fig. 14.3 (continued) 


\subsubsection{Summary and Implications for Future Directions}

Successful transition to post-school life and adulthood depends on how well a multidisciplinary team of professionals (e.g., current teachers, special education teachers, psychologists, medical doctors, guidance counselors, and staff of the new education institution), parents, and the person with ASD work in collaboration before and during the transition phase. Furthermore, it is important that ongoing social instructional support and future planning is provided throughout the postschool phase and emerging adulthood (ages 18-25) for persons with ASD.

Although there is an educational system in place for transition planning in Finland, there is a real need to develop the existing social and transition support services (Pesonen 2016). More and more, schools should focus on developing their person-centered planning strategies. Because current legislation does not mandate such planning, schools should ensure that it is in place. There should be support group services available during the transition period, groups that welcome all youth both with and without ASD (see Pesonen 2016). In addition, more emphasis should be placed on teacher preparation programs at the universities and at continuing inservice teacher trainings, so that those working with pupils with ASD in school receive the most recent knowledge and information about the transition plan. In sum, more efforts are needed to help individuals with ASD successfully transition to post-school life and adulthood.

\section{References}

Ahtiainen, R., Beirad, M., Hautamäki, J., Hilasvuori, T., Lintuvuori, M., \& Thuneberg, H. et al. (2012). Tehostettua ja erityistä tukea tarvitsevien oppilaiden opetuksen kehittäminen 20072011. Kehittävän arvioinnin loppuraportti [Development of special educational needs education between 2007 and 2011. Final report]. Helsinki, Finland: Ministry of Education.

Basic Education Act 628/1998. http://www.finlex.fi/en/laki/kaannokset/asiasanat.php?start=a\&id= 580163. Accessed 9 May 2017.

Brunila, K., Kurki, T., Lahelma, E., Lehtonen, J., Mietola, R., \& Palmu, T. (2011). Multiple transitions: Educational policies and young people's post-compulsory choices. Scandinavian Journal of Educational Research, 55(3), 307-324.

Camarena, P. M., \& Sarigiani, P. A. (2009). Postsecondary educational aspirations of high- functioning adolescents with autism spectrum disorders and their parents. Focus on Autism and Other Developmental Disabilities, 24, 115-128.

Cedefop (European Centre for Development of Vocational Training). (2012). Finland VET in Europe. Country Report 2012.Cedefop. http://libserver.cedefop.europa.eu/vetelib/2012/2012 CR_FI.pdf. Accessed 9 May 2017.

European Agency for Special Needs and Inclusive Education. (2015). Finland - overview. https:// www.european-agency.org/country-information/finland/national-overview/complete-nationaloverview. Accessed 9 May 2017.

Ferguson, P. M., Ferguson, D. L., \& Jones, D. (1988). Generations of hope: Parental perspectives on the transitions of their children with severe retardation from school to adult life. Journal of Association for Persons with Severe Handicaps, 13(3), 177-187. 
Finnish National Board of Education. (2016a). Upper secondary education and training. http:// www.oph.fi/english/education_system/upper_secondary_education_and_training. Accessed 9 May 2017.

Finnish National Board of Education (2016b). Support in upper secondary education and training. http://www.oph.fi/english/education_system/support_for_pupils_and_pupils/support_in_ upper_secondary_education_and_training. Accessed 9 May 2017.

Hendricks, D. R., \& Wehman, P. (2009). Transition from school to adulthood for youth with autism spectrum disorders: Review and recommendations. Focus on Autism and Other Developmental Disabilities, 24, 77-88.

Hirvonen, M., Ladonlahti, T., \& Pirttimaa, R. (2009). Ammatillisesta erityisopetuksesta tuettuun ammattiin opiskeluun - näkökulmia ammatillisen erityisopetuksen ja koulutuksen kehittämiseen. [From vocational special training to supported vocational studies - perspectives on the development of vocational special needs education.]. Kasvatus, 40(2), 158-167.

Honkanen, E., \& Nuutila, L. (2013). An overview of vocational special education and training in Finland. In K. Aaltonen, A. Isacsson, J. Laukia, \& L. Vanhanen-Nuutinen (Eds.), Practical skills, education and development: Vocational education and training in Finland (pp. 264275). Helsinki: Haaga-Helia University of Applied Sciences.

Itkonen, T., \& Jahnukainen, M. (2010). Disability or learning difficulty? Politicians or teachers? Constructing special education students in Finland and the United States. Comparative Sociology, 9(2), 182-201.

Jahnukainen, M. (1999). Winners or losers? A ten-year follow-up of twenty-three former students from special classes for the maladjusted in Finland. Young, 7(36), 36-49.

Jahnukainen, M., \& Järvinen, T. (2006). Risk factors and survival routes: Social exclusion as a life- historical phenomenon. Disability \& Society, 20(6), 669-682.

Kirjavainen, T., Jahnukainen, M., \& Pulkkinen, J. (2013). Työpaperi. Perusopetuksen erityisoppilaiden toisen asteen opinnot. 19.9.2013 (Working paper. Basic education students' education after basic education). Valtiontalouden tarkastusvirasto 68/54/2010. https://www.vtv.fi/ files/3566/Tyopaperi_Perusopetuksen_erityisoppilaiden_toisen_asteen_opinnot.pdf. Accessed 9 May 2017.

Kirjavainen, T., Pulkkinen, J., \& Jahnukainen, M. (2016). Special education pupils in transition to further education: A four-year register-based follow up study in Finland. Learning and Individual Differences, 45, 33-42.

Koulutuksen perusteet (Foundations of Schooling). (2015a). Työhön ja itsenäiseen elämään valmentava koulutus, Koulutuksen perusteet (Foundations of Schooling: Preparation for the workforce and independent living). Opetushallituksen määräys 6/011/2015 (executive order, Ministry of Education).

Koulutuksen perusteet (Foundations of Schooling). (2015b). Ammatilliseen peruskoulutukseen valmentava koulutus (Vocational preparation training). Opetushallituksen määräys 5/011/2015.

Laki ammatillisesta koulutuksesta (Vocational education legislation) 531/2017. https://www.finlex.fi/fi/laki/ajantasa/2017/20170531. Accesed 20 September 2019.

Myklebust, J. O. (2002). Inclusion or exclusion? Transitions among special needs students in upper secondary education in Norway. European Journal of Special Needs Education, 17(3), 251-263.

Newman, T., \& Blackburn, S. (2002). Transitions in the lives of children and young people: Resilience factors. Interchange 78. Edinburgh: Scottish Executive Education Department.

Official Statistics of Finland. (2007). Erityisopetus. Ammatillisen koulutuksen erityisopiskelijat koulutustyypin, erityisopetuksen perusteen ja sukupuolen mukaan 2007 (Special education. Vocational schooling and students with special education needs based on special support needs and gender 2017). Helsinki: Tilastokeskus. http://www.stat.fi/til/erop/2007/erop_2007_200906-10_tau_052.html. Accessed 9 May 2017.

Official Statistics Finland. (2012). Special education 2013. http://www.stat.fi/til/erop/2013/ erop_2013_2014-06-12_tie_001_en.html. Accessed 9 May 2017. 
Pesonen, H. (2016). Sense of belonging for students with intensive special education needs. An exploration of students' belonging and teachers' role in implementing support (Research report 380). Doctoral dissertation. Helsinki: Yliopistopaino Unigrafia.

Pesonen, H., Itkonen, T., Jahnukainen, M., Kontu, E., Kokko, T., Ojala, T., \& Pirttimaa, R. (2015). The implementation of new special education legislation in Finland. Educational Policy, 29(1), $162-178$.

Rydzewska, E. (2012). Destination unknown? Transition to adulthood for people with autism spectrum disorders. British Journal of Special Education, 39(2), 87-93.

Thuneberg, H., Vainikainen, M.-P., Ahtiainen, R., Lintuvuori, M., Salo, K., \& Hautamäki, J. (2013). Education is special for all: The Finnish support model. Belltz Juventa, Gemeinsam Leben, 2, 67-78.

Transitions. (n.d.). Autism society. Retrieved November 17, 2013, from http://www.autism-society. org/living-with-autism/lifespan/transitions.html

Van Bergeijk, E., Klin, A., \& Volkmar, F. (2008). Supporting more able students on the autism spectrum: College and beyond. Journal of Autism and Developmental Disorders, 38, 1359-1370.

Virolainen, M., \& Stenström, M.-L. (2014). Finnish vocational education and training in comparison: Strengths and weaknesses. International Journal for Research in Vocational Education and Training, 1(2), 81-106.

Vocational education and training in Finland. (n.d.). Vocational competence, knowledge and skills for working life and further studies. Finnish National Board of Education. http://www.oph.fi/ download/131431_vocational_education_and_training_in_finland.pdf. Accessed 9 May 2017.

Zager, D., \& Alpern, C. S. (2010). College-based inclusion programming for transition-age students with autism. Focus on Autism and Other Developmental Disabilities, 25, 151-157. 